\title{
EFFECT OF GINGER EXTRACT ON THE VIABILITY OF LACTIC ACID BACTERIA AND SENSORY CHARACTERISTICS OF DAIRY YOGHURT AND SOY YOGHURT
}

\author{
Adekunbi Adetola Malomo, Sumbo Henrietta Abiose \\ Address (es): Adekunbi Adetola Malomo \\ Department of Food Science and Technology, Obafemi Awolowo University, Ile - Ife, Nigeria. \\ *Corresponding author: adepojuadekunbi@gmail.com
}

\section{ABSTRACT}

Yoghurt is usually produced from cow milk which is unsuitable for vegetarian diet. Chemical preservative used for its preservation may have adverse effect on the lactic acid bacteria. This research was designed to evaluate the effect of ginger extract on the viability of lactic acid bacteria, physico-chemical property and sensory attributes of bio preserved functional yoghurt produced from dairy milk and soy milk during storage at refrigerated temperature. The result obtained showed that yoghurt produced from soy milk $(5.67-7.52 \mathrm{CFU} / \mathrm{ml})$ had higher lactic acid bacteria count than yoghurt from dairy milk $(4.71-7.31 \mathrm{CFU} / \mathrm{ml})$ throughout the period of storage. Ginger extract was more active against fungi in dairy yoghurt than $(0-5.09 \mathrm{CFU} / \mathrm{ml})$ soy yoghurt $(0-5.29 \mathrm{CFU} / \mathrm{ml})$. The pH was generally lower in dairy yoghurt $(4.29-4.67)$ than soy yoghurt $(4.69-5.14)$ while the titratable acidity was higher in dairy yoghurt $(1.30-2-01 \%)$ than soy yoghurt $(0.7-1.54 \%)$. Addition of ginger extract improved the texture and flavour of soy yoghurt. It is therefore suggested that functional yoghurt with good sensory attributes can be produced from soy milk and dairy milk using ginger extract as bio-preservative.

Keywords: yoghurt, dairy, soy milk, ginger, lactic acid bacteria

\section{INTRODUCTION}

Yogurt is one of the most widely distributed dairy products. It has a smooth texture, sour taste and pleasant flavor. It is obtained by inoculating dairy milk with Lactobacillus delbrueckii spp. bulgaricus and Streptococcus thermophilus (Qureshi et al., 2011). Its popularity and high consumption are due to its nutritional value and the therapeutic effects of starter bacteria during fermentation (Gündoğdu $\boldsymbol{e t}$ al., 2009). Lactic acid bacteria produce organic acids which exerts a positive effect on food through their activities during fermentation by imparting desirable flavors and inhibiting a variety of food spoilage and pathogenic organisms (Fowoyo and Ogunbanwo, 2010; Okpara et al., 2014; Malomo et al., 2018). The desirable flavor of yogurt is associated with the presence of several compounds; nonvolatile acids such as lactic and pyruvic, volatile acids such as butyric and acetic, and other components like amino acids and carbonyl compounds such as acetaldehyde and diacetyl (Yangilar and Yildiz, 2017). Yogurt produced from cow milk is consumed in both developing and developed countries. However, demands for alternatives to cow milk is growing day by day due to allergy, enriched nutrition and a desire for an alternative for vegetarian (Ranjana et al., 2016).

Legumes are sources of low-cost dietary vegetable proteins and minerals when compared with animal products such as meat, milk, fish and egg (Malomo et al., 2019). The usefulness of the legumes in developing high protein foods in meeting the needs of the vulnerable groups of the population is now well recognized, and several high protein energy foods have been developed industrially, in different parts of the world (Ayo et al., 2012).

Soybean (Glycine max) has been reported to contribute significantly towards protein, mineral, fat and B complex vitamins needs of people in developing countries. Fermentation of soymilk could modify or improve its flavor and texture so that it becomes more acceptable and can also lead to production of new types of soy product similar to cultured dairy products (Akabanda et al., 2010; Obadina et al., 2013). Different flavoring ingredients have been added during manufacturing of yoghurt to improve the flavor and artificial flavors are mostly used to improve yoghurt flavor during production.

The use of spices as flavor during yoghurt manufacturing could also be useful considering the fact that, they are plants rich in bioactive components with health benefits and constitute a potential source of minerals and vitamins in addition to their antimicrobial activities (Aswal et al., 2012; Njoya et al., 2018). The increase in the demand for safe foods, with less chemical additives, increased the study of bio preservatives, which do not injure the host or the environment (Olaniran et al., 2015). Ginger (Zingiber officinale) contains a fusion of aroma oils such as volatile and nonvolatile oils, pungent compounds (gingerols, shogaols), which have local effect on digestive system (Churbasik et al., 2005; Ozgoli et. al., 2009; Singh et al., 2017; Simeon et al., 2018). Many authors reported that it is endowed with antibacterial and antifungal properties (Al-Amin et al., 2006; Mendi, 2011; Njoya et al., 2018). This study was carried out with a view to determining the effect of ginger extract on the viability of lactic acid bacteria, safety and consumer perception of dairy and soy yoghurt preserved with ginger extract and to advance the use of soy milk in the production of yoghurt.

\section{MATERIALS AND METHODS}

Procurement of materials

Cow milk was obtained from a farm at Alakowe, Ile - Ife, ginger and commercial yoghurt starter culture were obtained from Oja tuntun, Ile - Ife. Soybean was obtained from Institute of Agricultural Research and Training, Ibadan.

\section{Production of dairy and soy yoghurt}

Modified method of Yangilar and Yildiz (2017) was used for the production of dairy yoghurt. Cow's milk was heated up to $85^{\circ} \mathrm{C}$ for $20 \mathrm{~min}$ and then cooled. Starter (Streptococcus thermophilus, Lactobacillus delbrueckii spp. bulgaricus and Lactobacillus acidophilus) was added in the milk (in the rate of 1.5\%). Ginger extract was incorporated into inoculated milk in different concentrations ( 2 and $4 \%$ ), incubated at $43^{\circ} \mathrm{C}$ for $10 \mathrm{~h}$ in an incubator and stored in the refrigerator $\left(4^{\circ} \mathrm{C} \pm 1\right)$ for further analysis.

Soy yoghurt was produced using modified method of Ranjana et al. (2016) Soybean was cleaned, washed and soaked for $12 \mathrm{~h}$ in water at room temperature. The beans were boiled for 20 min and hulls were removed by rubbing between palm and the resulting cotyledons blended. The resultant slurry was filtered through 3 layers of cheese-cloth and the residue was discarded. The supernatant was boiled for $30 \mathrm{~min}$ at $100^{\circ} \mathrm{C}$ and then cooled down to $35^{\circ} \mathrm{C}$. The soy milk obtained was divided into three portions. The first portion served as control, pasteurized aqueous ginger extract (2\%) was added to second portion and (4\%) to the third portion. Soy yoghurt was obtained by addition of commercial culture containing Streptococcus thermophilus, Lactobacillus delbrueckii spp. bulgaricus and Lactobacillus acidophilus. Starter culture (1.5\%) was added soy milk and incubated at $43^{\circ} \mathrm{C}$ for $10 \mathrm{~h}$ and stored in the refrigerator $\left(4{ }^{\circ} \mathrm{C} \pm 1\right)$ for further analysis.

\section{Preparation of aqueous ginger extract}

Ginger extracts was obtained from ginger paste by modified methods described by Kaushik and Goyal (2011) and Abd EI - Aziz et al. (2015) described by Njoya et al. (2018). Ginger root was washed, peeled and grated to form a paste. Decoction was done by boiling $50 \mathrm{~g}$ of ginger paste in $1.6 \mathrm{~L}$ of distilled water till one fourth $(1 / 4)$ of the initial volume was attained. The solution was filtered twice using a muslin cloth, allowed to sediment and the supernatant was collected. Extracts collected was pasteurized at $75^{\circ} \mathrm{C}$ for $15 \mathrm{~min}$, cooled at room temperature and kept in the refrigerator at $4 \pm 1^{\circ} \mathrm{C}$ for further uses. 


\section{Microbial analysis}

Yoghurt samples were analyzed on a weekly basis using the pour plate method. Samples $(5 \mathrm{ml})$ were weighed into stomacher bag and homogenized with $45 \mathrm{ml}$ of sterile maximum recovery diluent. The resulting mixture was serially diluted and $1.0 \mathrm{ml}$ of appropriate dilution was dispensed into Petri dish. Nutrient agar was used for total viable count, de Man Rogosa and Sharpe (MRS) agar for Lactic acid bacteria count and potato dextrose agar (PDA) for fungi count (Harrigan and McCance, 1976; Harrigan, 1998). Plates were incubated anaerobically for lactic acid bacteria at $35^{\circ} \mathrm{C}$ for $72 \mathrm{~h}$ and incubated in inverted position for total viable microorganisms and fungi at $35^{\circ} \mathrm{C}$ for $24 \mathrm{~h}$ and at $25^{\circ} \mathrm{C}$ for 3 to 5 days respectively (Harrigan, 1998). The colonies on each plate were counted using a Gallenkamp colony counter and pure isolates of the representative colonies were obtained by streaking on media of their primary isolation, incubated appropriately and kept in agar slant under refrigeration condition.

Bacteria isolates were identified using cultural and morphological characteristics, Gram's staining techniques and biochemical tests following the scheme of Harrigan and McCance (1976) and Wood and Holzapfel (1995). Fungi isolates were identified using colony characteristics, cell shape, size, type of budding and cell aggregation was determined by microscopy (Leica DM500 Model 13613210), and the ability of isolates to assimilate various carbon sources and nitrate were assessed (Beech et al., 1968; Barnett et al., 2000).

\section{pH of soy and dairy yoghurt}

$\mathrm{pH}$ meter (Scholar 425) was standardized with buffer 4.0 and 7.0. Yoghurt sample $(10 \mathrm{ml})$ was dispensed into a beaker and the electrode was inserted. The $\mathrm{pH}$ of the sample was recorded when the reading stabilized (AOAC, 2005).

\section{Titratable acidity of soy and dairy yoghurt}

Sample $(10 \mathrm{ml})$ was measured into conical flask, $10 \mathrm{ml}$ of distilled water was added and stirred to homogenize the sample. Three drops of phenolphthalein indicator was added to $10 \mathrm{ml}$ aliquots of filtrate and was titrated against $0.1 \mathrm{~N}$ $\mathrm{NaOH}$ (AOAC, 2005).

\section{Sensory evaluation}

A group of 15 experienced panelists chosen from the students and staff of the Department of Food Science and Technology, Obafemi Awolowo University, Ile - Ife evaluated the dairy and soy yogurt samples preserved with ginger. Panelists were presented with a cup filled with $100 \mathrm{ml}$ of each sample to score. Samples were evaluated for appearance, color, texture, flavor, and taste using 9 -point Hedonic scale where the lowest was 1 and highest was 7 . All the samples were provided the same test conditions and the panelist were allowed to clean their palates with water after tasting each sample (Yangilar and Yildiz, 2017).

\section{Statistical analysis}

Data obtained were subjected to Analysis of Variance using SPSS (version 17 incorporation, Chicago, Illinois, USA). Means of samples was separated using Duncan Multiple range Test.

\section{RESULTS AND DISCUSSION}

Effect of ginger extract on the viability of lactic acid bacteria count of dairy and soy yoghurt

The result of the lactic acid bacteria is shown in Table 1 . The count was generally higher in soy yoghurt $(5.67-7.52 \mathrm{CFU} / \mathrm{ml})$ than dairy yoghurt throughout the period of storage $(4.71-7.31 \mathrm{CFU} / \mathrm{ml})$. Lactic acid bacteria count decreased in both dairy yoghurt and soy yoghurt with increase in ginger extract. Soy yoghurt support the growth of lactic acid bacteria more than dairy yoghurt during the period of storage. This may be due to the

Table 1 Effect of Ginger Extract on the Lactic Acid Bacteria Count of Yoghurt (CFU/ml)

\begin{tabular}{lcccc}
\hline Samples & Week 0 & Week 1 & Week 2 & Week 3 \\
\hline SY0 & $7.52^{\mathrm{a}} \pm 0.03$ & $7.22^{\mathrm{a}} \pm 0.20$ & $7.31^{\mathrm{a}} \pm 0.02$ & $6.45^{\mathrm{a}} \pm 0.05$ \\
SY2 & $7.46 \mathrm{a} \pm 0.06$ & $7.05^{\mathrm{b}} \pm 0.03$ & $7.00^{\mathrm{b}} \pm 0.06$ & $6.13^{\mathrm{b}} \pm 0.02$ \\
SY4 & $7.43^{\mathrm{a}} \pm 0.03$ & $6.45^{\mathrm{c}} \pm 0.04$ & $6.53^{\mathrm{c}} \pm 0.01$ & $5.67^{\mathrm{c}} \pm 0.05$ \\
DY0 & $7.31^{\mathrm{bc}} \pm 0.01$ & $6.35^{\mathrm{d}} \pm 0.02$ & $5.09^{\mathrm{e}} \pm 0.03$ & $5.28^{\mathrm{d}} \pm 0.04$ \\
DY2 & $7.19^{\mathrm{cd}} \pm 0.08$ & $6.90^{\mathrm{d}} \pm 0.02$ & $5.68^{\mathrm{d}} \pm 0.05$ & $4.94^{\mathrm{e}} \pm 0.04$ \\
DY4 & $7.11^{\mathrm{d}} \pm 0.04$ & $6.40^{\mathrm{c}} \pm 0.05$ & $5.59^{\mathrm{d}} \pm 0.02$ & $4.71^{\mathrm{f}} \pm 0.01$ \\
\hline
\end{tabular}

SY0: Soy yoghurt; SY2- Soy yoghurt with $2 \%$ ginger extract; SY4- Soy yoghurt with $4 \%$ ginger extract; DY0: Dairy yoghurt; DY2: Dairy yoghurt with $2 \%$ ginger extract; DY4: Dairy yoghurt with $4 \%$ ginger extract. Values are means of three replicates \pm standard error. Means followed by different superscript in the same column are significantly different at $\mathrm{p}<0.05$ lower $\mathrm{pH}$ of the dairy yoghurt.

The reduction in lactic acid bacteria count could be due to accumulation of organic acids and waste products produced by bacterial activity such as hydrogen peroxide (Shah, 2000; Amal, 2013). The organic acid produced also gives the yoghurt its distinctive sour taste and pleasant aroma (Adepoju et al., 2012). Amal (2013) reported that the presence of soybean in fresh cow or camel milkyogurts significantly increased the Lactobacillus spp. compared to respective plain-yoghurt.

\section{Effect of ginger extract on the total viable count of dairy and soy yoghurt}

The total viable count of dairy and soy yoghurt is presented in Table 2. Count was significantly higher $(\mathrm{p}<0.05)$ in soy yoghurt $(6.05-7.76 \mathrm{CFU} / \mathrm{ml})$ than dairy yoghurt $(4.99-7.32 \mathrm{CFU} / \mathrm{ml})$ throughout the period of fermentation. Ginger extract which was used as both flavoring agent and bio-preservatives reduced the growth of the microorganisms in both soy and dairy yoghurt (4.99 $7.61 \mathrm{CFU} / \mathrm{ml})$. The higher the concentration of ginger, the lower the growth of microorganisms. Though the effect was not significant in dairy yoghurt without preservative and dairy yoghurt preserved with ginger from the beginning of storage to the second week but it was significantly lower $(p>0.05)$ at the third week. According to Adesokan et al. (2010), ginger could increase the shelflife of food due to its antimicrobial nature.
Table 2 Effect of Ginger Extract on the Total Viable Count Yoghurt (CFU/ml)

\begin{tabular}{lcccc}
\hline Samples & Week 0 & Week 1 & Week 2 & Week 3 \\
\hline SY0 & $7.76^{\mathrm{a}} \pm 0.03$ & $6.35^{\mathrm{c}} \pm 0.05$ & $7.76^{\mathrm{a}} \pm 0.04$ & $6.81^{\mathrm{a}} \pm 0.01$ \\
SY2 & $7.61^{\mathrm{ab}} \pm 0.09$ & $6.09^{\mathrm{d}} \pm 0.04$ & $7.37^{\mathrm{c}} \pm 0.02$ & $6.53^{\mathrm{b}} \pm 0.03$ \\
SY4 & $7.54^{\mathrm{b}} \pm 0.04$ & $6.05^{\mathrm{d}} \pm 9.05$ & $7.61^{\mathrm{b}} \pm 0.07$ & $6.13^{\mathrm{c}} \pm 0.02$ \\
DY0 & $7.32^{\mathrm{c}} \pm 0.02$ & $6.91^{\mathrm{a}} \pm 0.01$ & $5.70^{\mathrm{d}} \pm 0.03$ & $5.19^{\mathrm{d}} \pm 0.06$ \\
DY2 & $7.28^{\mathrm{c}} \pm 0.04$ & $6.88^{\mathrm{a}} \pm 0.03$ & $5.63^{\mathrm{d}} \pm 0.03$ & $5.03^{\mathrm{e}} \pm 0.03$ \\
DY4 & $7.21^{\mathrm{c}} \pm 0.03$ & $6.70^{\mathrm{b}} \pm 0.05$ & $5.13^{\mathrm{e}} \pm 0.05$ & $4.99^{\mathrm{e}} \pm 0.05$ \\
\hline
\end{tabular}

SY0: Soy yoghurt; SY2- Soy yoghurt with $2 \%$ ginger extract; SY4- Soy yoghurt with $4 \%$ ginger extract; DY0: Dairy yoghurt; DY2: Dairy yoghurt with $2 \%$ ginger extract; DY4: Dairy yoghurt with $4 \%$ ginger extract. Values are means of three replicates \pm standard error. Means followed by different superscript in the same column are significantly different at $\mathrm{p}<0.05$

\section{Effect of ginger extract on the fungi count of dairy and soy yoghurt}

The result of fungi count is shown in Table 3. There was no fungi growth in both dairy and soy yoghurt samples at week zero. Soy yoghurt had fungi count from week one to week three $(3.64-5.05 \mathrm{CFU} / \mathrm{ml})$ while dairy yoghurt had count at the third week $(4.01-4.58 \mathrm{CFU} / \mathrm{ml})$, Addition of ginger extract reduced the growth of fungi in the yoghurt samples. This showed that ginger is effective 
against fungi. Increase in fungi count could be as a result of production of acid by lactic acid bacteria which reduced the $\mathrm{pH}$ and enhanced yeast multiplication. During fermentation, bacteria provide the rapid acidic environment for fungi and the fungi provide essential metabolites such as pyruvates, vitamins and amino acids for the bacteria (Owuzu-Kwarteng and Akabanda, 2014; Malomo et al., 2019).

Table 3 Effect of Ginger Extract on the Fungiount Yoghurt (CFU/ml)

\begin{tabular}{lcccc}
\hline Samples & Week 0 & Week 1 & Week 2 & Week 3 \\
\hline SY0 & Nil & $4.48^{\mathrm{a}} \pm 0.04$ & $4.58^{\mathrm{a}} \pm 0.03$ & $5.29^{\mathrm{a}} \pm 0.01$ \\
SY2 & Nil & $3.70^{\mathrm{b}} \pm 0.01$ & $4.46^{\mathrm{b}} \pm 0.03$ & $5.05^{\mathrm{b}} \pm 0.03$ \\
SY4 & Nil & $3.64^{\mathrm{c}} \pm 0.02$ & $4.46^{\mathrm{b}} \pm 0.05$ & $4.89^{\mathrm{c}} \pm 0.06$ \\
DY0 & Nil & Nil & Nil & $4.09^{\mathrm{d}} \pm 0.04$ \\
DY2 & Nil & Nil & Nil & $4.01^{\mathrm{d}} \pm 0.03$ \\
DY4 & Nil & Nil & Nil & $4.58^{\mathrm{cd}} \pm 0.04$ \\
\hline
\end{tabular}

SY0: Soy yoghurt; SY2- Soy yoghurt with $2 \%$ ginger extract; SY4- Soy yoghurt with $4 \%$ ginger extract; DY0: Dairy yoghurt; DY2: Dairy yoghurt with $2 \%$ ginger extract; DY4: Dairy yoghurt with $4 \%$ ginger extract. Values are means of three replicates \pm standard error. Means followed by different superscript in the same column are significantly different at $\mathrm{p}<0.05$

Effect of ginger extract on microorganisms during storage of dairy and soy yoghurt

The occurrence pattern of microorganisms in dairy and soy yoghurt (Table 4) showed the dominance of lactic acid bacteria during storage. Lactobacillus delbrueckii spp. bulgaricus, Streptococcus thermophilus and Lactobacillus acidophilus were viable till the third week of storage. Bacillus subtilis was only isolated from soy yoghurt without ginger extract. Singh et al. (2017) reported that ginger showed antimicrobial activity against E coli, Salmonella typhi and Bacillus subtilis. Torulopsis versatilis was isolated from soy yoghurt without ginger extract and with $2 \%$ ginger extract from week one to week three but were isolated in soy yoghurt containing $4 \%$ ginger extract in week two and week three. Saccharomyces lactis was also isolated from all dairy yoghurt samples at week three. Lactic acid bacteria (LAB) are prominent in fermentation of food. They produce organic acids such as lactic acid, butyric acid, acetic acid and other metabolites from sugar present in food and this has positive effect on aroma, taste, texture and shelf life of food. LAB also produces antimicrobial substances known as bacteriocin which inhibit the growth and activities of pathogenic microorganisms. Their common occurrence in food contributes to their acceptance (Malomo et al., 2019). Bacillus spp. was also isolated from fermentation of legume-based food by different authors (Ezeama and Ihezie, 2006; Farinde et al., 2014, Malomo et al., 2019).

\section{Effect of ginger extract on the $\mathrm{pH}$ of dairy and soy yoghurt during storage}

The $\mathrm{pH}$ generally decreased in dairy yoghurt throughout the period of storage (Fig. 2). pH was a lower in dairy yoghurt (4.29 - 4.67) than soy yoghurt (4.695.14 ) as seen in Figure 1. Increase was observed in all soy yoghurt samples from week one to week three. Adepoju et al. (2012) attributed decrease in $\mathrm{pH}$ to metabolism of sugar which led to acid production by the relevant microorganisms. Addition of ginger increased the $\mathrm{pH}$ of both dairy and soy yoghurt. Ihemeje et al. (2015) also reported an increase in $\mathrm{pH}$ with addition of ginger.

Table 4 Effect of ginger extract on the microorganisms during storage dairy and soy yoghurt.

\begin{tabular}{|c|c|c|c|c|c|}
\hline Samples & Microorganism & Week 0 & Week 1 & Week 2 & Week 3 \\
\hline \multirow[t]{6}{*}{ SY0 } & Lactobacillus acidophillus & + & + & + & + \\
\hline & Lactobacillus delbrueckii spp. bulgaricus & + & + & + & + \\
\hline & Streptococcus thermophilus & + & + & + & + \\
\hline & Lactobacillus plantarum & + & + & + & + \\
\hline & Bacillus subtilis & - & + & + & + \\
\hline & Torulopsis versatilis & - & + & + & + \\
\hline \multirow[t]{5}{*}{ SY2 } & Lactobaccillus acidophillus & + & + & + & + \\
\hline & Lactobacillus delbrueckii spp. bulgaricus & + & + & + & + \\
\hline & Streptococcus thermophilus & + & + & + & + \\
\hline & Lactobacillus plantarum & + & + & + & + \\
\hline & Torulopsis versatilis & - & + & + & + \\
\hline \multirow[t]{5}{*}{ SY4 } & Lactobaccillus acidophillus & + & + & + & + \\
\hline & Lactobacillus delbrueckii spp. bulgaricus & + & + & + & + \\
\hline & Streptococcus thermo nnnnnnnilphilus & + & + & + & + \\
\hline & Lactobacillus plantarum & + & + & + & + \\
\hline & Torulopsis versatilis & - & - & + & + \\
\hline \multirow[t]{5}{*}{ DY0 } & Lactobacillus acidophillus & + & + & + & + \\
\hline & Lactobacillus delbrueckii spp. bulgaricus & + & + & + & + \\
\hline & Streptococcus thermophilus & + & + & + & + \\
\hline & Lactobacillus plantarum & + & + & + & + \\
\hline & Saccharomyces lactis & - & - & - & + \\
\hline \multirow[t]{6}{*}{ DY2 } & Lactobacillus acidophillus & + & + & + & + \\
\hline & Lactobacillus delbrueckii spp. bulgaricus & + & + & + & + \\
\hline & Streptococcus thermophilus & + & + & + & + \\
\hline & Lactobacillus plantarum & + & + & + & + \\
\hline & Bacillus subtilis & - & + & + & + \\
\hline & Saccharomyces lactis & - & - & - & + \\
\hline \multirow[t]{5}{*}{ DY4 } & Lactobacillus acidophillus & + & + & + & + \\
\hline & Lactobacillus delbrueckii spp. bulgaricus & + & + & + & + \\
\hline & Streptococcus thermophilus & + & + & + & + \\
\hline & Lactobacillus plantarum & + & + & + & + \\
\hline & Saccharomyces lactis & - & - & - & + \\
\hline
\end{tabular}

SY0: Soy yoghurt; SY2- Soy yoghurt with $2 \%$ ginger extract; SY4- Soy yoghurt with 4\% ginger extract; DY0: Dairy yoghurt; DY2: Dairy yoghurt with $2 \%$ ginger extract; DY4: Dairy yoghurt with $4 \%$ ginger extract. +: present; -: absent 


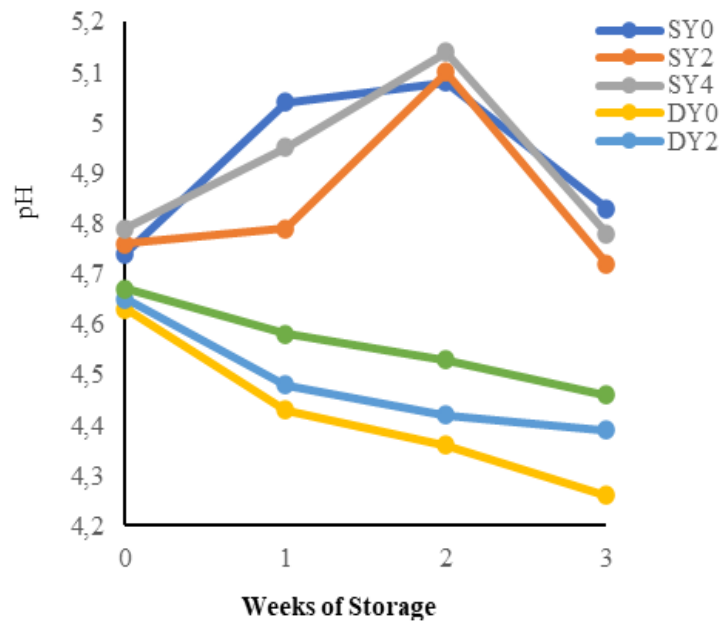

Figure 1 Effect of ginger extract on $\mathrm{pH}$ of dairy and soy yoghurt during storage SY0: Soy yoghurt; SY2- Soy yoghurt with $2 \%$ ginger extract; SY4- Soy yoghurt with 4\% ginger extract; DY0: Dairy yoghurt; DY2: Dairy yoghurt with $2 \%$ ginger extract; DY4: Dairy yoghurt with $4 \%$ ginger extract.

Effect of ginger extract on the titratable acidity of ginger spiced dairy and soy yoghurt sample during storage

The titratable acidity of ginger spiced yoghurt samples is compared in Fig. 2. The titratable acidity was generally lower in soy yoghurt $(0.7-1.54 \%)$ than dairy yoghurt $(1.30-2-01 \%)$ throughout the period of storage. The highest acidity in dairy yoghurt was observed in dairy yoghurt without ginger extract and it is the same with soy yoghurt. This is an indication that ginger can inhibit lactic acid bacteria from carrying out their normal activity. Acidity is accepted to take place among the significant factors influencing shelf life and consumer acceptability of yogurt (Al-Otaibi and El-Demerdash, 2008; Yangilar and Yildiz, 2017). The titratable acidity decreased with increase in ginger extract in both soy and dairy yoghurt. The reduction of titratable acidity of yoghurt with the increase in ginger extract could be due to the dilution effect (Njoya et al., 2018). Obadina et al. (2013) attributed decrease in $\mathrm{pH}$ and increase in titratable acidity to the accumulation of some organic acid and acetic acid resulting from the activities of some fermentative organisms such as lactic acid bacteria and yeasts in the fermenting foods.

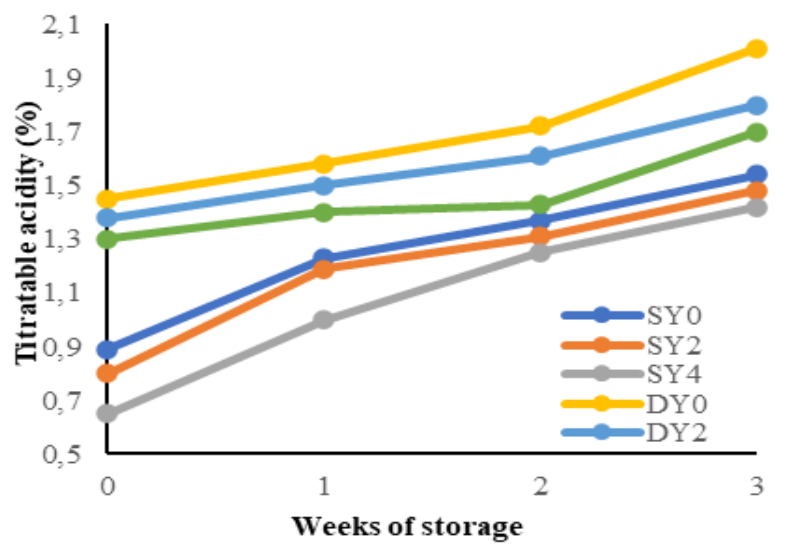

Figure 2 Effect of ginger extract on the titratable acidity of dairy and soy yoghurt sample during storage.

SY0: Soy yoghurt; SY2- Soy yoghurt with $2 \%$ ginger extract; SY4- Soy yoghurt with $4 \%$ ginger extract; DY0: Dairy yoghurt; DY2: Dairy yoghurt with $2 \%$ ginger extract; DY4: Dairy yoghurt with $4 \%$ ginger extract.

\section{Effect of ginger extract on sensory assessment of soy and dairy yoghurt}

The result of the sensory assessment carried out on dairy yoghurt and soy yoghurt is seen in Table 5. Dairy yoghurt $(5.8-6.7)$ had significantly higher $(\mathrm{p}<0.05)$ score than soy yoghurt $(4.4-4.7)$ and addition of extract ginger did not have significant effect $(\mathrm{p}>0.05)$ on the color of both dairy and soy yoghurt samples. Soy yoghurt containing $4 \%$ ginger had the highest score for texture and the score is not significantly different $(p>0.05)$ from other yoghurt samples. Ginger contains an important amount of starch (up to $40 \%$, dry basis) with several potential applications which is considered as one of the most thickening agents used for yogurt manufacturing (Ibrahim, 2015). There was no significant difference $(p>0.05)$ in the flavor of spiced dairy and soy yoghurt. The flavor of dairy yoghurt decreased with increase in ginger extract while the flavor score of soy yoghurt increased. There was no significant difference $(p>0.05)$ in the taste of ginger spiced dairy and soy yoghurt. Ginger extract had no significant effect on both dairy and soy yoghurt samples but rather increased the overall acceptability of soy yoghurts. Score for overall acceptability shows similarities between spiced dairy and soy yoghurt. The refreshing pleasant aroma, biting taste and carminative property of ginger makes it as an indispensable ingredient of food processing throughout the world (Singh et al., 2017).

Table 5 Mean Sensory Score for Soy and Dairy Yoghurt Preserved with Ginger Extract

\begin{tabular}{lccccc}
\hline Samples & Colour & Texture & Flavour & Taste & $\begin{array}{c}\text { Overall } \\
\text { acceptability }\end{array}$ \\
\hline DY0 & $6.7^{\mathrm{a}} \pm 0.67$ & $5.4^{\mathrm{a}} \pm 1.35$ & $6.1^{\mathrm{a}} \pm 0.88$ & $6.6^{\mathrm{a}} \pm 0.52$ & $6.6^{\mathrm{a}} \pm 0.70$ \\
DY2 & $6.2^{\mathrm{a}} \pm 0.63$ & $5.4^{\mathrm{a}} \pm 1.79$ & $5.8^{\mathrm{ab}} \pm 0.63$ & $5.7^{\mathrm{a}} \pm 0.67$ & $5.9^{\mathrm{ab}} \pm 0.73$ \\
DY4 & $5.8^{\mathrm{a}} \pm 1.03$ & $5.5^{\mathrm{a}} \pm 1.45$ & $5.4^{\mathrm{a}} \pm 0.84$ & $5.6^{\mathrm{a}} \pm 0.84$ & $5.7^{\mathrm{a}} \pm 0.82$ \\
SY0 & $4.4^{\mathrm{b}} \pm 1.51$ & $4.8^{\mathrm{a}} \pm 1.48$ & $4.4^{\mathrm{b}} \pm 1.65$ & $4.4^{\mathrm{b}} \pm 1.65$ & $4.2^{\mathrm{c}} \pm 1.75$ \\
SY2 & $4.7^{\mathrm{b}} \pm 1.57$ & $5.4^{\mathrm{a}} \pm 0.70$ & $5.4^{\mathrm{ab}} \pm 0.70$ & $4.6^{\mathrm{b}} \pm 1.58$ & $4.6^{\mathrm{b}} \pm 1.42$ \\
SY4 & $4.4^{\mathrm{b}} \pm 1.65$ & $5.6^{\mathrm{a}} \pm 1.35$ & $5.3^{\mathrm{ab}} \pm 0.95$ & $4.6^{\mathrm{b}} \pm 1.51$ & $4.4^{\mathrm{bc}} \pm 1.51$ \\
\hline SY0:
\end{tabular}

SY0: Soy yoghurt; SY2- Soy yoghurt with $2 \%$ ginger extract; SY4- Soy yoghurt with $4 \%$ ginger extract; DY0: Dairy yoghurt; DY2: Dairy yoghurt with $2 \%$ ginger extract; DY4: Dairy yoghurt with $4 \%$ ginger extract.

\section{CONCLUSION}

Functional yoghurt with appealing aroma and taste can be produced from both dairy milk and soy milk by using ginger extract as bio preservative. Ginger extract extended the shelflife of both dairy and soy yoghurt and had minimal effect on the viability of the lactic acid bacteria. It also inhibited the activities of fungi and pathogenic microorganisms during storage. Addition of ginger extract also improved the texture, taste and flavour of soy yoghurt. This research suggested that functional yoghurt similar to dairy yoghurt with acceptable microbiological and organoleptic quality can be also produced from soymilk for especially for vegetarian and low-income earners.

Acknowledgements: The authors appreciate Mr. Oluwabukunmi Alakija and Mrs B. I. Oluwafemi for their technical assistance during the course of this project.

\section{REFERENCES}

Abd El - Aziz, M., Mohamed, S.H.S., Seleet, F.L., Abd El- Gawad, M.A.M. 2015. Effect of brine solution containing ginger extracts on the properties of Egyptian white brine cheese. American Journal of Food Technology, 101, 37-47. Adepoju, A. A., Abiose, S. H., Adeniran, H. A. 2012. Effect of Some Preservation Techniques on the Microbiological Characteristics of Fura de Nunu during Storage. Ife Journal of Technology, 21(2): 30 - 37.

Adesokan, I.A., Abiola, O.P., Ogundiya, M.O. 2010. Influence of ginger on sensory properties and shelf-life of Ogi, a Nigerian traditional fermented food. African Journal of biotechnology, 9, 1803 - 1809.

Amal, B. S. 2013. Antioxidant activity and viability of lactic acid bacteria in soybean-yogurt made from cow and camel milk. Journal of Taibah University for Science, 7, 202-208 https://.dx.doi.org/10.1016/j.jaubas.2011.11.001

Akabanda, F., Owusu-Kwarteng, J.R.L.K., Glover, R.L.K., Tano-Debrah, K. 2010 Microbiological characteristics of Ghanian traditional fermented milk product, Nunu. Nature Science, 8(9), 178 - 187. 
Al-Otaibi, M., El-Demerdash, H. 2008. Improvement of the quality and shelf life of concentrated yogurt (labneh) by the addition of some essential oils. African Journal of Microbiology Research, 2, 156-161.

AOAC. 2005. Official Method of Analysis. Association of Official Analytical Chemist. Washington D. C, U. S. A

Ayo, J. A, Onuoha, G., Agu, H., Ayo, V. A., Avu, E. O., Sosanya, M., Adeosun, F. (2012). Effect of Added Beneseed Paste on the Quality of Millet-Based Masa. African Journal of Food Science and Technology, 3(10), 236-243.

Aswal, P., Shukla, A., Priyadarshi, S. 2012.Yoghurt: preparation, characteristics and recent Advancements. Cibtech Journal of Bio-Protocols, 12, 32-44.

Barnett, J. A., Payne, R. W., Yarrow, D. 2000. Yeasts: Characteristics and Identification. Third ed. Cambridge University Press, Cambridge.

Beech, F.W., Davenport, R. R., Goswell, R.W., Burnett, J. K. 1968. In: Gibbs, B. M., and Shapton, D. A., Identification Methods for Microbiologists. Part B, Academic Press, London.

Chrubasik, S., Pittle, M.H., Roufogalis, B. D. 2005. Zingiberis rhizome: a comprehensive review on the ginger effect and efficacy profiles. Phytomedcine, $12,684-701$

Gündoğdu, E., Çakmakçi, S., Dağdemir, E. 2009. The Effect of Garlic (Allium sativum L.) on Some Quality Properties and Shelf-Life of Set and Stirred Yoghurt. Turkey Journal of Vetinary Animal Science, 33(1), 27-35

Ezeama, C., Ihezie, C. I. 2006. Microbiological and Sensory Evaluations of Fermented Rice Snacks (Masa) Supplemented with Soybean. Journal of Food Technology, 4 (4), 345-349.

Farinde, E. O., Adeniran, H. A., Abiose, S. H. 2014. Comparative Microbial Assessment of Fermented Lima Bean (Phaseolus lunatus) and Locust Bean (Parkia biglobossa) in Production of Daddawa. British Microbiology Research Journal, 4(7), 772-784

Harrigan, J. R., McCance, M. (1976). Laboratory Methods in Food and Dairy Microbiology, Academic Press, London. Pp 69 - 102

Harrigan, W.F. 1998. Laboratory Methods in Food and Dairy Microbiology, Academic Press San Diego, C.A. pp. 97 - 102

Ibrahim, A. H. 2015. The effects of various stabilizers on physiochemical properties of camel milk yoghurt. American Journal of Science, 11, 15-24 Ihemeje, A., Nwachukwu, C. N., Ekwe, C. C. 2015. Production and quality evaluation of flavoured yoghurts using carrot, pineapple and spiced yoghurt using ginger and pepper fruit. African Journal of Food Science, 9(3), 163-169. https://dx.doi.org/10.5897/AJFS2014.1244

Kaushik, P., Goyal, P. 2011. Evaluation of Various Crude Extracts of Zingiber officinale Rhizome for Potential Antibacterial Activity: A Study in Vitro. Advance Microbiolology, 1, 7-12. https://dx.doi.org/10.4236/aim.2011.11002

Malomo, A. A., Abiose, S. H., Adeniran, H. A. 2018. Microbiological Changes during the Production of Maize-Acha Masa Fortified with Soybean. Annals. Food Science and Technology, 19(2), 349 - 357.

Malomo, A. A., Abiose, S. H., Adeniran, H. A. 2019. Effects of Substitution of Acha and Soybean on Alpha amylase Activity, Sugars and Total Free Amino Acid during Production of Maize Masa. Journal of Microbiology, Biotechnology and Food Science, 9(3), 534 - 538

https://dx.doi.org/10.15414/jmbfs.2019/20.9.3.534-538

Njoya, M. A., Ejoh, A. R., Kuiate, J., Nain, C. W., Kuboh, D. A., Audra, F. 2018. Effect of ginger extract on the physicochemical and sensory Properties of yoghurt. International Journal of Development Research, 8(5), 20468-20477

Obadina, A.O.1, Akinola, O.J., Shittu, T.A., Bakare, H.A. Effect of Natural Fermentation on the Chemical and Nutritional Composition of Fermented Soymilk Nono. Nigerian Food Journal, 31(2), 91 - 97

Okpara, A. N., Okolo B. N., Ugwuanyi, J. O. 2014. Antimicrobial Activities of Lactic Acid Bacteria Isolated from Akamu and Kunun-Zaki (Cereal Based NonAlcoholic Beverages) In Nigeria. African Journal of Biotechnology, 13(29): 2977- 2984.

Olaniran, A. F., Abiose, S. H., Adeniran, H. A. 2015. Biopreservative effect of ginger (Zingiber officinale) and garlic powder (allium sativum) on tomato paste. J. Food Safety, 35, 440-452. https://dx.doi.org/10.1111/jfs.12193

Owusu-Kwarteng, J., Akabanda, F. 2014. Soybean Fortification of Maasa: A Ghanaian Fermented Millet-Based Cake. Canadian Journal of Pure and Applied Science, 8(1), 2733-2738.

Ozgoli, G., Goli, M., Simbar M. 2009. Effects of ginger capsules on pregnancy, nausea, and vomiting. The J. Alternative and Complementary Med.15(3), 243246. https://dx.doi.org/10.1089/acm.2008.040
Qureshi, A.M., Hassan, S.Y., Sulariya, A.M., Rashid, A. A. 2011. Preparation and nutritional evaluation of garlic-based yogurt. Science International (Lahore), 23(1), 59-62.

Ranjana, S., Nivedita, S., Shweta, H. 2016. Nutritional and quality attributes of fortified soy yogurt prepared by using probiotic food grade lactic acid bacteria. Indian Journal of Dairy Science, 69(4), 441 - 446

Simon, H. P., Chandra, R., Shukla, S., Singh, S. S. 2018. Sensory evaluation of probiotic herbal yoghurt with ginger and garlic extract. The Pharma Innovation Journal, 7(4), 605-607

Yangilar, F., Yildiz, P.O. 2017. Effects of using combined essential oils on quality parameters of bio-yogurt. Journal Food Processing and Preservation, 42, 1- 9. https://dx.doi.org/10.1111/jfpp.13332

Singh, R. P., Gangadharappa, H. V., Mruthunjaya, K. 2017. Ginger: A Potential Neutraceutical, An Updated Review. International Journal of Pharmacognosy $\begin{array}{llll}\text { and Phytochemical } & \text { Research, } & \text { 1227-1238 }\end{array}$ https://dx.doi.org/10.25258/phyto.v9i09.10311

Shah, N.P. (2000). Probiotic bacteria: Selective enumeration and survival in dairy products. Journal of Dairy Science, 83, 894-907.

Wood, B. J. B., Holzapfel, W. H. 1995. The Genera of Lactic Acid Bacteria. Vol. 2. Blakie Academic and Professional, an Imprint of Chapman and Hall, Wester Cleddens Road, Bishopbriggs, Glasgow G64 2NZ. Pp, 12 - 36 